\title{
Osteotomia Valgizante de tíbia com placa "calço" de Puddu: apresentação de técnica*.
}

Valgus tibial osteotomy with "wedge" plate of Puddu: technique presentation*

\section{RESUMO}

O objetivo do presente trabalho é apresentar os resultados iniciais, obtidos com a osteotomia valgizante de adição de tíbia, fixada com placa calço descrita por Puddu. Foram operados 29 joelhos em 27 pacientes para correção de geno-varo, sendo que, em apenas um paciente o procedimento bilateral teve objetivo profilático. O seguimento foi de 3 a 28 meses com média de 14 meses. A osteotomia proximal de tíbia foi feita de forma oblíqua iniciando na inserção distal do ligamento colateral medial em direção ao tubérculo de Gerdy. A osteotomia foi aberta e fixada com uma placa calço de Puddu. O espaço aberto da osteotomia foi preenchido por enxerto autólogo de ilíaco. A carga total era dada com 45 dias de pós-operatório. Os resultados obtidos mostraram que entre 4 a 6 meses os pacientes tiveram uma significativa melhora na sintomatologia indutora do procedimento cirúrgico. A avaliação final mostrou 27 resultados satisfatórios e apenas 2 regulares. Como conclusão essa técnica tornou a osteotomia de tíbia um procedimento reprodutível com resultados previsíveis com excelente manutenção no pósoperatorio da correção obtida no trans-operatório.

Descritores: Osteoartrose. Geno-varo. Osteotomia

\section{SUMMARY}

The objective of this paper is to present the initial results obtained with the valgus tibial osteotomy, fixed with the wedge plate described by Puddu. This surgery was performed in 29 knees, in 27 patients, for correction of genu-varum, and as a profilatic measure in only one patient. The follow up time was from 3 to 28 months with average of 14 months. The proximal tibial osteotomy was done in an oblique way with start in the distal insertion of the colateral medial ligament and directed to the Gerby tubercle. The osteotomy was opened and fixed with a wedge plate of Puddu. The space opened by the osteotomy was filled with autologous iliac graft. Total weightbearing was allowed 45 days after surgery. The results show that in 4 to 6 months patients had a significant improvement of symptoms which induced to the surgical procedure. The final evaluation shows 27 satisfactory results and only 2 regular. Concluding, this technique made the tibial osteotomy a reproducible procedure with predictable results and excellent mantainance in the post-surgery of the correction obtained during surgery.

Key-words: Osteoartrosis, Genu-varum. Osteotomy 


\section{INTRODUÇÃO}

A degeneração femoro-tibial medial do joelho freqüentemente deixa o ortopedista em dúvida sobre qual a melhor conduta a ser empregada ${ }^{5}$. Todas as técnicas cirúrgicas descritas tem por objetivo transferir para o lado lateral, ainda que parcialmente, a sobrecarga existente no compartimento medial em função de uma deformidade em varo, para melhorar a distribuição da pressão $0^{5,6,9,10}$. Embora convergentes quanto ao objetivo a ser atingido, essas diferentes técnicas divergem quanto à simplicidade de realização, dos resultados obtidos, complicações associadas ao trans-operatório e cuidados no pósoperatório ${ }^{2,3,4,8,9,10,12,13,15,16,17,18}$. Devido a essa desuniformidade de técnicas e resultados, surgiram desde propostas alternativas de solução puramente video-artroscópicas ${ }^{7}$ até novos modelos de próteses uni-compartimentais ${ }^{5,14}$.

Continuávamos indecisos e relutantes quanto à indicação de osteotomias tibiais até sermos apresentados pelo seu idealizador, Dr. Giancarlo Puddu (Roma,Italia), ao que nos pareceu uma idéia simples e lógica: a osteotomia proximal de abertura fixada com placa calço ${ }^{1,11}$. O objetivo do presente trabalho é apresentar os resultados obtidos com essa técnica com base no tratamento de 29 pacientes portadores de deformidade em varo do joelho.

\section{CASUÍSTICA E MÉTODOS}

Durante o período compreendido entre julho de 1997 e agosto de 1999, 29 joelhos de 27 pacientes portadores de deformidade em varo do joelho foram tratados pela técnica de osteotomia proximal de abertura da tíbia fixada com placa calço e presa com dois parafusos, sendo um esponjoso e um cortical

A idade dos pacientes variou de 17 à 79 anos, com uma média de 52 anos e 6 meses. O número de pacientes do sexo masculino foi de 16 e do sexo feminino foi de 11. A média de idade dos pacientes do sexo masculino foi de 44 anos e 3 meses, e do sexo feminino foi de 60 anos e 9 meses.

Todos os pacientes potencialmente candidatos ao procedimento eram radiografados em pé, em apoio monopodal e bipodal, em extensão completa do joelho. O ângulo de varismo era medido apenas para avaliação do resultado final obtido no pós-operatório, já que a correção trans-operatória da deformidade baseava-se num referencial puramente visual.

\section{Técnica Cirúrgica}

O procedimento inicial consistia em uma vídeo-artroscopia cirúrgica ${ }^{7,13}$, que tinha por objetivo lavar a articulação de debris cartilaginosos, ressecar lesões meniscais e tratar lesões cartilaginosa por meio de curetagem, perfurações ou abrasão ${ }^{7,18}$. A seguir, dava-se início à osteotomia ${ }^{1,11}$ propriamente dita, através de uma incisão longitudinal de pele de aproximadamente $5 \mathrm{~cm}$ de comprimento, na face medial de metáfise tibial, à $4 \mathrm{~cm}$ da interlinha articular. Identificava-se o ligamento colateral medial superficial, que era seccionado transversalmente $1 \mathrm{~cm}$ acima de sua inserção tibial. Nesse ponto era introduzido um fio de Kirschner em direção ao tubérculo de Gerdy (fig. 2.2). Sua orientação era então avaliada no intensificador de imagens,

\section{INTRODUCTION}

The medial femoro-tibial degeneration of the knee often brings doubts to the orthopedist upon which would be the better technique to be choosen ${ }^{5}$. All surgical tecniques described have the objective of shifting the weight load present in the medial compartment, due to a varum deformity, to the lateral side, at least partially, aiming a better distribution of pressure 5,69,10. Although having the same objective, these several techniques are different with respect to the simplicity of its execution, results obtained, complications during surgery and care after surgery $2,3,4,8,9,10,12,13,15,16,17,18$. Due to these differences of techniques and results, alternative solutions appeared, from solely videoarthroscopic techniques ${ }^{7}$ to new models of unicompartimental prosthesis ${ }^{5,14}$

We were reluctant to indicate the tibial osteotomies until we learned from Dr. Giancarlo Puddu (Rome, Italy) a technique developed by him, the proximal osteotomy with opening fixed with wedge plaque, what appeared to be a simple and logic idea ${ }^{1,11}$. The objective of this paper is to present the results obtained with this technique in the surgical treatment of 29 patients with varum deformity of the knee.

\section{MATERIAL AND METHODS}

From July/97 to August/99, 29 knees from 27 patients bearing a varum deformity were treated with the technique of proximal osteotomy with tibial opening fixed with plaque wedge fixed with two screws, one spongiosus and one cortical.

The age of our patients ranged from 17 to 79 years old, with average of 52 years and 6 months. Sixteen patients were male and 11 female. The average age of male patients was 44 years and 3 months and for female patients was 60 years and 9 months.

All candidates to the procedure had a X-ray standing, with mono and bipodal support, with complete extension of the knees. The varum angle was measured for evaluation of final result obtained after surgery, since the correction of the deformity during surgery was based solely in the visual appearance.

\section{Surgical Technique}

The initial procedure was a surgical video-artroscopy $y^{7,13}$, with the objective of wash the articulation from cartilagenous debris, ressect the menisc lesions and treat the cartilagenous lesions trough curetage, perforations and abrasion ${ }^{7,18}$. Following started the osteotomy ${ }^{1,11}$ itself, with a longitudinal incision with circa $5 \mathrm{~cm}$ in the skin, in the medial side os the tibial metaphisis, $4 \mathrm{~cm}$ away from the articular interline. The colateral medial superficial ligament was identified and transversaly cut $1 \mathrm{~cm}$ above its tibial insertion. In this point a thread of Kirschner was introduced and oriented to the Gerdy tubercle (Fig. 2.2). Its orientation was evaluated with the image amplifier, and modified if necessary. When the orientation was acceptable, the thread was cut $1 \mathrm{~cm}$ above its entry in the 
podendo ser mudada se considerada insatisfatória. Se a orientação fosse considerada aceitável, cortava-se o fio a $1 \mathrm{~cm}$ do ponto de entrada na tíbia. O objetivo deste fio era servir de guia para a lâmina da serra óssea. O corte tibial tinha início abaixo e rente a este fio de Kirschner (fig 2.3). A progressão deste corte, transversal ao eixo da tíbia, também era monitorado no intensificador de imagem. Uma vez terminado o corte tibial(fig 2.4), a osteotomia era completada com o diapasão, que possui forma de cunha (fig.2.5), graduado em sua extensão. Esse instrumento é a chave de todo o procedimento, porque ao mesmo tempo que completa a osteotomia, permite que se varie a correção para mais ou menos até o ponto desejado, escolhendo-se o tamanho da placa pela graduação externa visível na lateral do diapasãocunha (fig. 1).

O grau de correção clínica era avaliado com o pé do paciente apoiado contra o abdomen do cirurgião. Se fosse considerado insuficiente, o diapasão-cunha era empurrado mais para dentro do corte tibial, aumentando a correção. Se a correção fosse considerada demasiada, bastava que o diapasão-cunha fosse puxado um pouco para fora do corte tibial, diminuindo imediatamente o grau de correção. Quando a correção considerada ideal era alcançada, colocava-se a placa correspondente ao número da lateral externa do diapasão-cunha. Esse número varia de 7,5 à $15 \mathrm{~mm}$, sendo a placa colocada por dentro do diapasão, de tal forma que quando ele era retirado, a placa mantinha a correção obtida. Proximalmente, a placa era fixada com um parafuso esponjoso longo, que ficava praticamente paralelo à linha da osteotomia. Distalmente, a placa era fixada por um parafuso de cortical (fig. 2.6). A estabilização trans-operatória foi excelente em todos os casos. Nesse momento, o defeito ósseo era preenchido com enxerto ósseo autólogo de ilíaco.

Em todos pacientes usou-se dreno de aspiração por 24 horas. O ferimento era fechado por planos e o joelho protegido por um imobilizador longo com barbatanas de alumínio. Esse imobilizador era mantido por 3 semanas, mas os pacientes eram estimulados a realizarem exercícios de flexo-extensão à partir do $10^{\circ}$ dia pósoperatório. O apoio parcial teve início no $15^{\circ}$ dia e a carga total no $45^{\circ}$ dia pós-operatório. Todos os pacientes fora acompanhados radiologicamente no pós- operatório (Fig 3 e 4).

tibia. The objective of this thread was to act as a guide to the disk of the bone sewer. The tibial cut was started below and close to this thread of Kirschner (Fig. 2.3). The progression of this cut, transversal to the tibial axis, was also monitored with help from the image amplifier. Once the tibial cut was finished (Fig. 2.4), the osteotomy was completed with the diapason, that has the shape of a wedge (Fig. 2.5), graded in its extension. This instrument is the key of the whole procedure, because at the same time it completes the osteotomy, it permits a variation for more or for less in the correction up to the desired point, being the size of the plaque chosen according to the graduation externally visible in the lateral side of the diapason-wedge (Fig. 1).

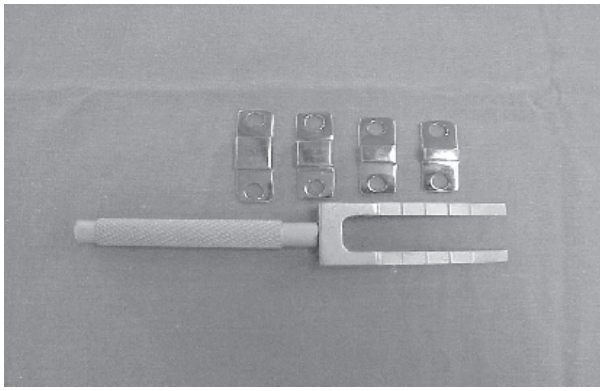

Figura 1: Mostrando o diapasão-cunha e as placas calço de Puddu.

Figure 1: Shows the diapason-wedge and the wedge

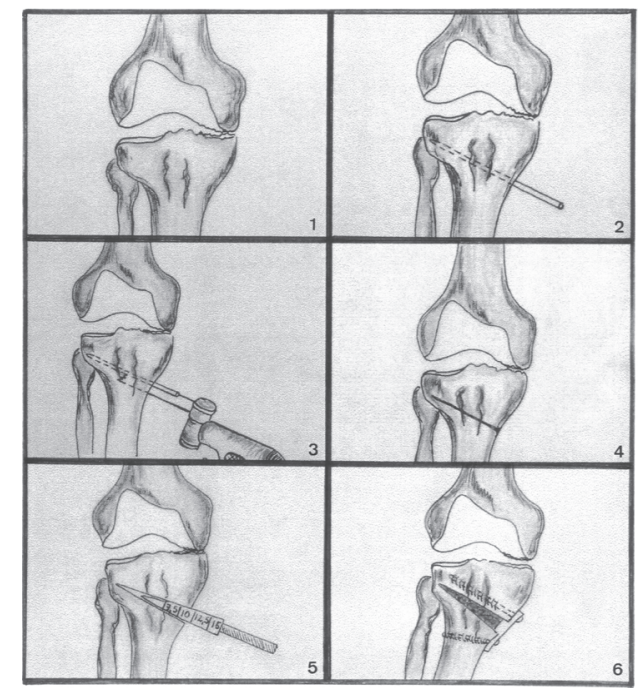

Figura 2: Procedimento cirúrgico, passo a passo em esquema, numerado pela ordem de aparecimento no texto.

Figure 2: Surgical procedure, step by step, schematic, numbered according to the appearance in the text surgery (Fig. 3 and 4).
The degree of clinical correction was evaluated with the foot of the patient placed against the abdomen of the surgeon. If considered insufficient, the diapason-wedge was pushed inside the tibial cut, increasing the correction. If the correction was considered too great, the diapason-wedge was pulled outside, decreasing instantly the degree of correction. When the correction was considered as ideal, a plaque corresponding to the lateral number in the diapason-wedge was put in place. This number ranges from 7,15 to $15 \mathrm{~mm}$, and the plaque was placed inside the diapason, in a way that when it was displaced, the plaque would keep the same correction achieved. Proximally the plaque was fixed with a long spongiosus screw, pratically standing parallel to the osteotomy line. Distally, the plaque was fixed with a cortical screw (Fig. 2.6) The stabilization during surgery was excellent in all cases. In this moment the bone defect was filled with autologous iliac bone gralfit. all patients was used a aspiration device for 24 hours. The wound was closed layer by layer and the knee was protected with a long imobilizer with aluminum fins. The imobilizer was kept for 3 weeks, but patients were encouraged to do flexo-extension exercises starting in the $10^{\text {th }}$ postoperative day. Partial weightbearing started in the $15^{\text {th }}$ day and total weightbearing in the $45^{\text {th }}$ postop day. All patients were monitored radiologically after 


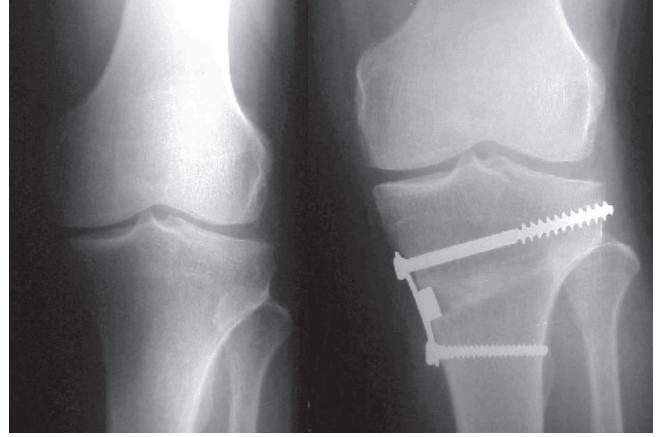

Figura 3: Radiografia de frente pré-operatória e pós-operatória (42 dias da cirurgia). Mostrando correção adequada do varismo da tíbia.

Figure3: Pre and Postoperative radiography (42 days after surgery), showing the adequate correction of tibial varum

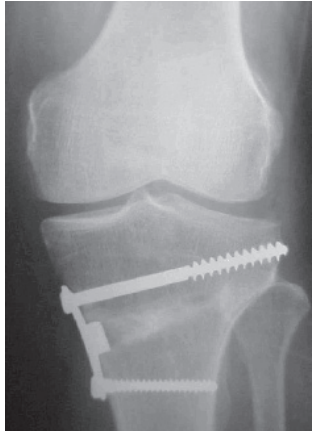

Figura 4: Estudo radiográfico após 63 dias, mostrando perfeita integração do enxerto ósseo.

Figure 4: Radiographic study after 63 days, showing perfect integration of bone graft

\section{Critério de Avaliação dos Resultados}

Utilizamos na revisão dos casos os critérios de avaliação constantes do quadro $1^{3}$

\section{QUADRO 1}

\begin{tabular}{|l|l|}
\hline Resultados Satisfatórios & $\begin{array}{l}\text { * correção completa da deformidade } \\
\text { *ausência de dor. } \\
\text { * recuperação da amplitude de movimentos em } \\
\text { relação ao pré-operatório. }\end{array}$ \\
\hline Resultados Regulares & $\begin{array}{l}\text { * correção completa da deformidade. } \\
\text { * alivio parcial da dor. } \\
\text { * perda mínima da amplitude de movimentos. }\end{array}$ \\
\hline Resultados Insatisfatórios & $\begin{array}{l}\text { * correção incompleta da deformidade. } \\
\text { * presença de dor. } \\
\text { * limitação importante da amplitude de movimento. }\end{array}$ \\
\hline
\end{tabular}

\section{RESULTADOS}

Utilizamos para avaliação primária dos resultados, a classificação subjetiva em: satisfatórios, regulares e insatisfatórios, de acordo com o quadro $1^{3}$

Pela nossa avaliação classificamos 27 joelhos como satisfatórios, 1 joelho como regular e 1 joelho como resultado insatisfatório. Como complicação tivemos um caso de infecção superficial que necessitou a realização de limpeza cirúrgica com desbridamento, apresentando boa evolução com antibioticoterapia e curativos. Não foi necessário a retirada da placa com os parafusos e do enxerto autólogo colocado para preencher a falha óssea. Este paciente apresentou dor moderada e limitação parcial da flexão do joelho (resultado insatisfatório). Em todos os casos ocorreu completa integração do enxerto ósseo autólogo (fig.5).

\section{Criteria for Assessment of Results}

The evaluation criteria that appear in Table $1^{3}$ were used review the cases

\section{TABLE 1}

\begin{tabular}{|c|c|}
\hline Satisfactory Results & $\begin{array}{l}{ }^{*} \text { complete correction of deformity. } \\
\text { ^ absence of pain. } \\
\text { * recovery of movements amplitude related to the } \\
\text { pre-operative. }\end{array}$ \\
\hline Regular Results & $\begin{array}{l}\text { “ complete correction of deformity. } \\
\text { * partial improvement of pain. } \\
\text { * minimum loss of movements amplitude. }\end{array}$ \\
\hline Non-satisfactory Results & $\begin{array}{l}\text { * incomplete correction of deformity. } \\
\text { * presence of pain. } \\
\text { * major limitation of movements amplitude. }\end{array}$ \\
\hline
\end{tabular}

\section{RESULTS}

To evaluate the results the subjective classification in satisfactory, regular and non-satisfactory, was used. Table $1^{3}$

According to our evaluation we classified 27 knees as satisfactory, 1 knee as regular and 1 knee as non-satisfactory result. As complication we had one case of superficial infection that required surgical cleaning, with good outcome after antibiotic treatment and bandages. It was not

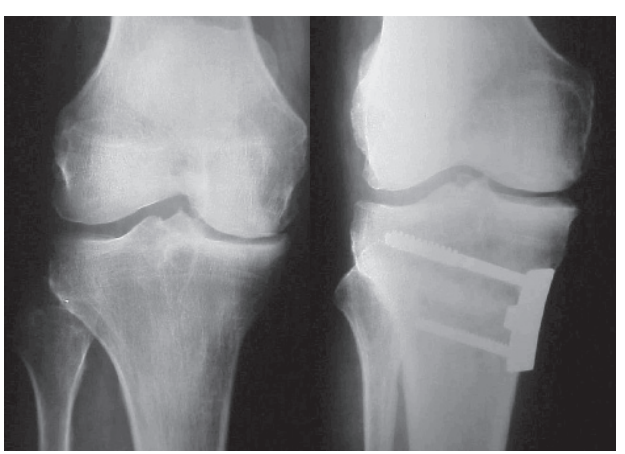
necessary the outplacement of the plaque with screws and autologous bone graft placed to fill the bone imperfections. This patient presented with moderate pain and partial limitation of knee flexion nonsatisfactory result). In all cases occurred complete integration of the autologous bone graft (Fig. 5)

Figura 5: Estudo radiográfico, com carga, pré e pós-operatório, mostrando abertura da interlinha articular medial com 45 dias e integração perfeita do enxerto ósseo.

Figure 5: Radiographic study, with load, pre and post-operatively, showing the opening of the medial articular interline after 45 days and perfect integration of the bone graft. 


\section{DISCUSSÃO}

A correção cirúrgica com a placa de Puddu'11 é um procedimento que, na nossa opinião, vai revolucionar o tratamento das deformidades em varo do joelho, com ou sem doença degenerativa do compartimento medial. As razões para isso são muitas, mas vamos discorrer sobre aquelas que nos parecem ser as principais. Começaremos por analisar a metodologia do procedimento cirúrgico. Ela é especialmente eficiente na correção profilática das deformidades em varo em pacientes jovens. Basta que o tamanho da placa utilizada em um lado seja igual ao do outro para termos uma correção totalmente simétrica. Mas consideramos especialmente atraente a reversibilidade trans-cirúrgica da correção obtida. Essa flexibilidade é alcançada simplesmente, empurrando para dentro ou puxando para fora o diapasão-cunha, para obter-se assim maior ou menor correção, sem comprometimento do resultado final. Nenhum corte ósseo adicional é necessário, tudo se resolve apenas com o corte tibial inicial. A estabilização trans-cirúrgica da osteotomia é excelente, mas o mais importante é que essa correção se mantém inalterada no pós- operatório.

O outro aspecto interessante é a baixa morbidade local, não só devido à pouca mobilidade tecidual, mas também devido a manutenção da integridade da fíbula e da articulação tibiofibular proximal. Como a fíbula não é tocada, passa a funcionar como uma tala biológica aumentando a estabilização da osteotomia. Essa baixa morbidade local diminui a chance de complicações tão comuns nas osteotomias convencionais ${ }^{16}$, especialmente em pacientes com mais idade. Certamente alguém dirá que esta cirurgia obriga a retirada de enxerto do ilíaco, no que somos obrigados a concordar. Entretanto, em função da distância dos dois procedimentos, não ocorre uma superposição das morbidades locais, sendo ambos perfeitamente tolerados pelos pacientes. Além disso, existe a possibilidade do defeito ósseo tibial ser preenchido por outros métodos que não o enxerto autólogo, o que diminuiria ainda mais a morbidade geral. No nosso hospital, já iniciamos um protocolo que inclui 3 grupos de pacientes tratados com enxerto liofilizado, enxerto homólogo congelado e pastilhas de hidroxiapatita. Como são ainda poucos casos, não foram incluídos no presente trabalho, mas obviamente o pós- operatório imediato destes pacientes foi mais tranqüilo do que o daqueles em que foi empregado enxerto autólogo.

Talvez a maior dificuldade que encontramos em todo esse procedimento, foi como nos referir a placa que fixa a osteotomia

Poderíamos simplesmente nos referir à ela como placa de Puddu, nome do seu idealizador. Ocorre que atualmente essas placas estão sendo comercializadas pela Artrexâ, fábrica de material ortopédico, que em conjunto com o Dr. Peter Fowler e o Dr. A. Amendola ${ }^{1}$, introduzia várias modificações no modelo original, que nos foi mostrado pelo Dr. Giancarlo Puddu ${ }^{11}$ alguns anos atrás. Assim sendo, criar-se-ia uma certa confusão, pois teríamos placas de Puddu original e a placa da Artrexâ , ou quem sabe, a placa Puddu-Fowler. Pelo que pudemos abservar até agora, as mudanças introduzidas são mais de ordem cosmética do que conceitual, ou seja, alterações na forma e não no conteúdo. Por essas razões, prefirimos nos ater ao conceito de placa com protuberância variável. Pensamos inicialmente em

\section{DISCUSSION}

The surgical correction with plaque of Pudd $u^{1,11}$ is a procedure that, in our opinion, will considerably change the treatment of the varum deformities of knee, with or without degenerative disease of the medial compartment. The reasons for this are many, but here are those we judge as the most important. We will start with the analysis of the surgical procedure methodology. It is specially efficient in the profilatic correction of the varum deformities in young patients. It is enough that the plaque size used in one side be similar to the one used in the other side to have a totally symetric correction We consider particularly atractive the transsurgery reversibility of the obtained correction. This flexibility is achieved by pulling inside or pushing outside the diapason-wedge, to obtain more or less correction, without compromising the final result. No additional bone cut is necessary. All is solved by the initial tibial cut. The stabilization transsurgical of the osteotomy is excellent, but the the most important is that this correction is kept unchanged in the postoperative time.

Another interesting aspect is the low local morbidity, not only due to the reduced tissular mobility, but also due to the mantainance of the fibular and proximal tibiofibular articulation integrity. As the fibula is not touched, it works as a biological stabilizer increasing the stability of the osteotomy. This low local morbidity decreases the chance of complications very frequent in the conventional osteostomies ${ }^{16}$, mainly in elderly patients. Certainly one will say that this surgery requires collection of bone graft from iliac, and we are obliged to agree. However, considering the anatomical distance of both procedures, there is no superimposed local morbidity, and both procedures are perfectly tolerated by patients. Moreover, exists the possibility of the tibial bone defect be filled in by methods other than the autologous graft, what would decrease additionally the global morbidity. In our hospital, we started a study with 3 groups of patients treated with liophilized graft, frozen homologous graft and tablets of hidroxiapatite. No nosso hospital, já iniciamos um protocolo que inclui 3 grupos de pacientes tratados com enxerto liofilizado, enxerto homólogo congelado e pastilhas de hidroxiapatite.

Maybe the major difficulty faced in this whole procedure, was how to name the plaque that fixes the osteotomy.

We could simply call it plaque of Puddu, name of surgeon who developed this procedure. It happens that such plaques are sold by Artrex ${ }^{\circledR}$, factory of orthopedic material, that together with $D r$. Peter Fowler and Dr. A. Amendola', will introduce several modifications to the original model, shown to us by Dr. Giancarlo Puddu ${ }^{11}$ some years ago. Thus, the confusion is created, because we would have the Puddu original plaque and the Artrex ${ }^{\circledR}$ plaque, ou who knows, the plaque Puddu-Fowler. from what we could observe up to now, the changes intrduced are more cosmetics than conceptual, that means, changes in the format and not in the content. Due to these reasons we prefer stick to concept of plaque with variable protuberance. We have thought initially in plaque of addition ou plaque step, but concluded that these are designations that do not express in a satisfactory way the function of the plaque. Our option was in favor of plaque-wedge, that in spite of phonetically disagreable, is an expression that naturally translates the objective and format of the plaque in question. 
placa de adição ou placa degrau, mas concluímos que são designações que não expressam satisfatoriamente a função da placa. Optamos por placa-calço, que apesar de foneticamente pouco atraente, é uma expressão que naturalmente traduz o objetivo e a forma da placa em questão.

Independente do nome escolhido, o que realmente conta quando se trata de osteotomia de tibia, é que o meio é tão importante quanto o fim. Sob este aspecto, o osteotomia valgizante de tíbia com placa calço de Puddu atingiu o objetivo final, ou seja, correção da deformidade com distinção, além de proporcionar aos pacientes uma evolução pós-operatória surpreendentemente fácil para toda a alteração estrutural decorrente do procedimento. Como último adendo, gostaríamos de tranqüilizar os mais cépticos dizendo-lhes que independentemente da osteotomia habitualmente supratuberositária tornar-se ocasionalmente trans-tuberositária, não tivemos nenhum caso de comprometimento do aparelho extensor

\section{CONCLUSÃO}

A qualidade dos resultados obtidos até o momento, aliados a simplicidade trans-operatória, a segurança do manejo pósoperatório, o baixo número de complicações nos levaram a concluir que a técnica empregada resgatou a osteotomia proximal da tíbia ao ofuscamento determinado pela prótese total do joelho. Viabilizando novamente a sua indicação como uma alternativa atraente para o tratamento do joelho varo por osteoartrose uni-compartimental medial.

\section{REFERÊNCIAS}

1. Amendola, A.,Fowler, P.J. \& Puddu, G.: Opening wedge high tibial osteotomy: Rationale and surgical technique, video presented at the $65^{\text {th }}$ meeting of the American Academy of Orthopaedic Surgeons, New Orleans, Louisiana, march 1923, 1998.

2. Camargo, O.P.A., Severino, N.R., Aihara, T., Cury, R.P.L., Souza, D.G., Palomino, E.M. \& Cillo, M.S.P.: Osteotomia tibial alta: estudo comparativo entre os métodos de fixação por "agrafes" e aparelho de llizarov. Rev Bras Ortop 30: 305310, 1995.

3. Cerqueira, N.B., Souza, J.M.G. \& Fonseca, E.A.: Osteotomia alta da tíbia em "V" invertido no tratamento da artrose do joelho. Rev Bras Ortop 28: 273-276, 1993.

4. Cameron, H.U., Welsh, R.P., Jung, Y.B. \& Noftall, F.: Repair of nonunion of tibial osteotomy. Clin Orthop 287: 167169,1993.

5. Dearborn, J.T., Eakin, C.L. \& Skinner, H.B.: Medial compartment arthrosis of the knee. Am J Orthop 25: 1826,1996.

6. Ecker, M.L. \& Lotke, P.A.: Spontaneous osteonecrosis of the knee. J Am Acad Orthop Surg 2: 173-178,1994.

7. Johnson, L.L.: Chondral conditions; in Jonhson, L.L.; Arthroscopic Surgery, St. Louis, The C.V. Mosby Company, 1986, 669-783

8. Miniaci, A., Ballmer, F.T., Ballmer, P.M. \& Jakob, R.P.: Proximal tibial osteotomy: a new fixation device. Clin Orthop 246: 250259,1989 .
Regardless of the chosen name, what really counts, as far as tibial osteotomy is concerned, it is that the ways are so important as the end. Under this aspect, the tibial valgisant osteotomy with wedge-plate of Puddu reached its final objective, that is, correction of the deformity and a postoperative time very easy for patients in spite of all structural changes of this procedure. As last words, we would like to tranquilize the more skepticals saying that, regardless of the fact that osteotomies usually supratuberositary have ocasionally become transtuberositary, we had no case of committment of the extensor aparatus.

\section{CONCLUSION}

The quality of the results obtained up to this moment, besides the transoperative simplicity, the safety of the postoperative handling and the low number of complications led us to conclude that the technique used rescued the proximal tibial osteotomy from the shadow brought by the total knee prosthesis turning once more its indication as one attractive alternative to the treatment of varum knee due to unicompartimental medial ostheoarthrosis.

9. Murphy, S.B.: Tibial osteotomy for genu varum. Indications, preoperative planning, and technique. Orthop Clin North Am 25: 477-482,1994

10. Nagel, A., Insall, J.N. \& Scuderi, G.R.: Proximal tibial osteotomy: a subjective outcome study. J Bone Joint Surg[Am] 78: 1353-1358,1996.

11. Puddu, G.: Comunicação pessoal. $1^{\circ}$ Biennal Congress ISAKOS, Buenos Aires, Argentina, May,1997.

12. Stetson, W.B., Friedman, M.J., Fulkerson, J.P., Cheng, M. \& Buuck, D.: Fracture of the proximal tibia with immediate weightbearing after a Fulkerson osteotomy. Am J Sports Med 25: 570-574,1997.

13. Vidal, P.C., Brandt, C., Paulo, H., Gomes, M.M. \& Tavares,S.: Tratamento da osteoartrose do joelho com artroscopia e osteotomia valgizante tibia empregando o aparelho de llizarov. Rev Bras Ortop 30: 523-527,1995.

14. Weale, A.E. \& Newman, J.H.: Unicompartmental arthroplasty and high tibial osteotomy for osteoarthosis of the knee. A comparative study with a 12 to 17 year follow-up period. Clin Orthop 302: 134-137,1994.

15. Wildner, M., Peters, A., Hellich, J. \& Reichelt, A. Complications of high tibial osteotomy and internal fixation with staples. Arch Orthop Trauma Surg 111: 210-212,1992.

16. Wootton, J.R., Ashworth, M.J. \& Maclaren, C.A.: Neurological complications of high tibial osteotomy - the fibular osteotomy as a causative factor: a clinical and anatomical study. Ann R Coll Surg Engl 77: 31-34,1995.

17. Zaidi, S.H., Cobb, A.G. \& Bentley, G.: Danger to the popliteal artery in high tibial osteotomy. J Bone Joint Surg [Br] 77: 384-386, 1995.

18. Zuegel, N.P., Braun, W.G., Kundel, K.P. \& Rueter, A.E.: Stabilization of high tibial osteotomy with staples. Arch Orthop Trauma Surg 115: 290-294,1996. 